\title{
Pembelajaran Memahami Struktur Teks Prosedur Melalui Model Teams Games Tournament (TGT) Pada Siswa Kelas VIII SMP Negeri 1 Essang
}

\author{
Gustiadi Saia, Ferry H. Mandang, Ruth C. Paath \\ Jurusan Pendidikan Bahasa dan Sastra Indonesia, Fakultas Bahasa dan Seni, Universitas Negeri \\ Manado \\ gustiadisaia@gmail.com,ferrymandang@unima.ac.id,ruthpaath@unimaac.id
}

\begin{abstract}
Abstrak: Penelitian ini bertujuan menggambarkan (1) proses pembelajaran memahami struktur teks prosedur melalui model Teams Games Tournament (TGT) pada siswa kelas VIII SMP Negeri 1 Essangdan (2) kemampuan siswa kelas VIII SMP Negeri 1 Essang memahami struktur teks prosedur dengan model Teams Games Tournament (TGT). Penelitian ini menggunakan metode deskriptif analitik. Sumber data adalah siswa kelas VIIIa SMP Negeri 1 Essang yang berjumlah 21 orang.Teknik pengumpulan data yang digunakan adalah observasi, wawancara, dan tes. Teknik analisis data menggunakan analisis deskriptif untuk menggambarkan proses pembelajaran memamahi teks prosedur dengan model TGT yang berlangsung dan rumus hitung persentase untuk menghitung kemampuan siswa memahi teks prosedur. Hasil penelitian yang diperoleh menunjukkan bahwa proses pembelajaran memahami struktur teks prosedur dengan model TGT menciptakan suasana kelas menyenagkan, membuat siswa bekerja sama secara aktif, saling berbagi, dan saling bertukar pendapat, sehingga tidak membosankan. (2) Terlaksananya pembelajaran dengan model TGT dengan baik memberi efek yang positif terhadap kemampuan siswa memahami struktur teks prosedur. Nilai rata-rata klasikal yang diperoleh siswa kelas VIII SMP Negeri 1 Essang adalah 84.52 dengan kualifikasi mampu dan melampaui ketuntasan minimal, yang ditetapkan oleh guru mata pelajaran bahasa Indonesia, yakni 75. Dari 21 siswa yang mengikuti tes, 20 orang siswa $(95.30 \%)$ memperoleh nilai ketuntasan, karena memperoleh nilai 75 ke atas, sedangkan hanya 1 orang siswa (4.70\%) harus mengikuti remedial, karena belum tuntas atau belum mencapai nilai 75 sebagai kriteria ketuntasan minimal.
\end{abstract}

Kata Kunci: kemampuan, struktur teks prosedur, model TGT

\section{PENDAHULUAN}

Keterampilam membaca merupakan keterampilan yang penting bagi siswa di era sekarang ini dalam rangka menerima dan menyaring beragam informasi. Harris dan Sipay (dalam Wiratin, 2004:14) menyatakan bahwa membaca merupakan suatu kegiatan memberikan respon makna secara tepat terhadap lambang verbal yang tertulis. Pemahaman terjadi dari interaksi antara persepsi simbol-simbol grafis dan keterampilan bahasa serta pengetahuan pembaca. Dalam interaksi ini, pembaca berusaha menciptakan kembali makna sebagaimana makna yang ingin disampaikan oleh penulis dalam tulisannya.

Dengan memiliki kemampuan membaca, siswa dapat menyerap ilmu pengetahuan yang sedang dipelajarinya. Hal ini sesuai dengan pendapat Burns dkk (1996:5) yang menyatakan bahwa kemampuan membaca merupakan kemampuan yang vital dalam masyarakat melek huruf seperti masyarakat dewasa ini. Anak yang tidak memiliki kemampuan membaca yang baik tidak akan termotivasi untuk belajar. Sebaliknya, anak yang memiliki kemampuan membaca yang baik, akan termotivasi dalam belajar. Oleh karena itu, pengajaran membaca mempunyai kedudukan yang sangat penting dalam proses belajar mengajar di sekolah.

Dimilikinya kemampuan membaca merupakan kemampuan yang vital dalam masyarakat di era teknologi digital dewasa ini. Sangatlah masuk akal Syafi'ie (1993:42) mengemukakan bahwa pengajaran membaca mempunyai kedudukan yang sangat strategis dalam proses belajar mengajar di sekolah. Bahkan, kemampuan membaca merupakan kemampuan yang harus dimiliki siswa dalam 
rangka melanjutkan studi. Dengan keterampilan membaca, mereka akan mengikuti perkembangan ilmu dan dapat mengambil manfaat dari berbagai ilmu itu, sehingga studinya berjalan lancar dan berhasil.

Pentingnya keterampilan membaca bagi siswa di sekolah, mengharuskan pembelajaran membaca beragam teks wajib mendapatkan perhatian yang besar dari guru bahasa Indonesia. Namun demikian, kenyataannya pembelajaran membaca di sekolah belum dilaksanakan secara optimal. Hal itu diduga akibat dari pelaksanaan pembelajaran yang masih terikat dengan penggunaan strategi konvensional dalam pembelajaran membaca pemahaman.

Hasil pengamatan sementara penulis di SMP Negeri 1 Essang, menunjukkan bahwa kemampuan membaca pemahaman siswa perlu ditingkatkan. Hal ini dibuktikan dengan adanya fakta seperti: (1) siswa masih menemui kesulitan dalam memahami isi bacaan secara utuh, (2) siswa masih kesulitan mengungkapkan pesan/informasi yang tersirat dalam bacaan secara lisan atau tulis dan (3) siswa kurang termotivasi mengikuti pembelajaran membaca. Kondisi siswa yang demikian diduga salah satu disebabkan kurang bervariasinya strategi atau model pembelajaran yang digunakan guru. Guru masih berpegang pada pola pembelajaran yang lama, yakni menerapkan model pembelajaran yang konvensional, seperti ceramah, sehingga pembelajarannya menjadi transfer pengetahuan. Siswa pasif dan hanya mendengar guru menerangkan materi yang dipelajari. Dampaknya, siswa kurang bergairah dan termotivasi mengikuti pembelajaran membaca sebuah teks.

Pengoptimalan pembelajaran membaca teks prosedur perlu dilakukan, sebab di dalam teks prosdur kaya akan informasi-informasi penting yang perlu dimiliki siswa cara mengerjakan/menggunakan sesuatu atau cara menghasilkan sesuatu. Melalui belajar teks ini siswa dilatih berpikir sistematis. Teks prosedur termasuk dalam jenis teks faktual (Mahsun, 2014:30). Karena itu, dalam Kurikulum 2013, memahami teks prosedur adalah salah kompetensi dasar wajib yang dipelajari oleh siswa SMP kelas VIII pada semester ganjil. KD pembelajaran adalah "menelaah struktur teks prosedur cara melakukan sesuatu dan cara membuat sesuatu". Berhasilnya pembelajaran memahami struktur teks prosedur akan berjalan dengan baik apabila diikuti pemilihan model pembelajaran yang tepat. Salah satu model pembelajaran yang cocok digunakan yakni Teams Games Tournament (TGT)

Model Teams Games Tournament (TGT) adalah suatu model pembelajaran, yang dalam aktivitas pembelajarannya membagi siswa ke dalam kelompok-kelompok yang kecil berlomba mengerjakan sesuatu. Kurniasari (https;//rizardian.blogspot.com/2012/11/) mengemukakan model pembelajaran TGT merupakan salah satu model pembelajaran kooperatif dengan membentuk kelompok kecil (3-5) orang, yang akan melaksanakan permainan dalam turnamen akademik bersaing dengan kelompok lain untuk prestasi yang terbaik.

Model TGT mudah diterapkan guru dalam kelas. Dengan demikian model TGT dapat diterapkan untuk menciptakan kelas yang dinamis. Pembelajaran tidak hanya didominasi oleh guru, tetapi dapat dikembangkan melalui aktivitas siswa melalui perlombaan dan permainan, sehingga membuat suasana belajar aktif tidak membosankan. Karena itu, penulis tertarik untuk meneliti pembelajaran membaca teks prosedur melalui model Teams Games Tournament (TGT) pada siswa kelas VIII SMP Negeri 1 Essang.

penelitian ini bertujuan (1) menggambarkan proses pembelajaran menelaah struktur teks prosedur menghasilkan sesuatu melalui model Teams Games Tournament (TGT) pada siswa kelas VIII SMP Negeri 1 Essang dan (TGT) dan (2) menggambarkan kemampuan siswa kelas VIII SMP Negeri 1 Essang menelaah struktur teks prosedur menghasikan sesuatu dengan model Teams Games Tournament (TGT)menelaah.

\section{METODE}

Penelitian ini menggunakan rancangan metode deskriptif analitik. Metode deskriptif analitik adalah salah satu jenis metode penelitian yang berusaha meneliti pada kondisi obyektif yang alamiah dengan maksud mendeskrispikan dan menganalisis gejala-gejala dan fakta-fakta yang terjadi terhadap sesuatu objek yang diamati. Metode ini cocok digunakan untuk meneliti pembelajaran menelaah struktur teks prosedur dengan model Tour Group Tournament (TGT). Metode ini juga digunakan oleh Mundung, 
S., Pelelalu, \& Meruntu. (2014) dalam penelitian yang berjudul, Penerapan Model Kooperatif Concept Sentences dalam Pembelajaran Menulis Narasi Siswa Kelas VII SMP Negeri 3 Ranoyapo.

Penelitian dilaksanakan di SMP Negeri 1 Essang. Waktu penelitian dilaksanakan bulan Juli Agustus 2018 pada semester ganjil, Tahun Pelajaran 2018/2019. Adapun yang menjadi sumber data dalam penelitian ini adalah siswa kelas VIIIa SMP Negeri 1 Essang berjumlah 21 orang. Teknik Penelitian yang digunakan adalah observasi, wawancara, dan tes.

Observasi digunakan untuk mengamati berlangsungnya pembelajaran menelaah struktur teks prosedur dengan model TGT pada siswa kelas VIII SMP Negeri 1 Essang. Wawancara dilakukan dengan guru dan siswa untuk memperoleh informasi mengenai tanggapan atau kesan mereka terhadap pelaksanaan pembelajaran menelaah struktur teks prosedur dengan model TGT. Tes digunakan untuk memperoleh data kemampuan siswa memahami teks prosedur adalah menggunakan tes membaca, khususnya mengukur kemampuan membaca pemahaman secara literal dan intpretatif. Untuk memperoleh data mengenai kemampuan siswa memahami struktur teks prosedur digunakan kisi-kisi penilaian. Aspek penilaian untuk mengetahui kemampuan siswa menentukan struktur teks prosedur sesuai dengan pendapat Mahsun (2014:30).

Dalam penelitian ini menggunakan teknik analisis data deskriptif yaitu menganalisis data hasil pengamatan dan wawancara. Selain itu, penelitian ini juga menggunanakan teknik analisis data secara kuatitatif, untuk mengolah hasil tes membaca, khususnya menelaah struktur teks prosedur yang diperoleh siswa . Rumus untuk menghitung hasil tes digunakan rumus persentase. Untuk mengetahui kemampuan siswa dalam menelaah struktur teks prosedur digunakan juga kriteria keberhasilan.

\section{HASIL DAN PEMBAHASAN}

\section{Proses Pembelajaran Menelaah Struktur Teks Prosedur Melalui Model Teams Games Tournament (TGT) pada Siswa Kelas VIII SMP Negeri 1 Essang}

Terdapat lima komponen utama yang perlu dilaksanakan dalam belajar kooperatif model TGT, yakni (1) presentasi kelas, (2) kegiatan kelompok, (3) permainan (games), (4) turnamen (tournament) dan (5) penghargaan terhadap usaha kelompok. Oleh sebab itu, proses pembelajaran menelaah struktur teks prosedur dengan model TGT, yang telah dilaksanakan dalampenelitian dideskripsikan sesuai urutan lima langkah pembelajaran utama model TGG. Proses pembelajaran yang berlangsung dideskripsikan berikut.

\section{1) Tahap Presentasi Kelas}

Tahap presentasi kelas, adalah tahap awal yang dilaksanakan dalam pembelajaran TGT. Kegiatan diawali oleh guru berupa membuka pelajaran. Guru menyapa siswa, menanyakan keadaan siswa, memotivasi siswa untuk siap belajar, melakukan apersepsi untuk mengaktifkan skemata siswa. Pembentukan skemata dilakukan agar pengetahuan siswa yang berkaitan dengan topik bacaan dapat diaktifkan. Sebagai langkah awal, guru bertanya aktivitas yang dilakukan siswa saat di rumah.

Setelah skemata siswa diaktifkan, maka guru menghubungkan pengetahuan yang dimiliki siswa dengan Kompetensi Dasar pelajaran yaitu "Memahami struktur teks prosedur". Setelah itu, guru menjelaskan tujuan dan manfaat pembelajaran. Materi pelajaran dipresentasikan lebih lanjut secara langsung kepada siswa. Secara garis besar guru menguraikan pengertian teks prosedur, menjelaskan ciri/karakterisitk teks prosedur, dan unsur-unsur teks prosedur. Guru juga menampilkan contoh teks prosedur di papan tulis dan menjelaskan struktur teks prosedur kepada siswa. Saat guru menjelaskan struktur teks prosedur, siswa diminta membuat catatan mengenai materi yang dijelaskan oleh guru. Guru juga menuliskan hal-hal penting mengenai teks prosedur di papan tulis, sehingga membuat siswa mudah memahami teks prosedur, apalagi guru menjelaskan teks prosedur melalui contoh teks.

\section{2) Kegiatan Kelompok (Team)}

Kegiatan kelompok merupakan inti pembelajaran dari BK model TGT. Kegiatan kelompok dilakukan setelah guru mempresentasikan pelajaran. Berdasarkan materi pelajaran yang telah dipresentasikan, guru membagikan tugas yang akan dipelajari dan dikerjakan oleh siswa. Materi pelajaran harus dikuasai oleh setiap kelompok. Oleh karena itu, apabila ada anggota dalam kelompok 
mengalami kesulitan memahami tugas yang diberikan guru, anggota tersebut harus dibantu oleh teman dalam kelompok. Untuk mengerjakan tugas, siswa diberi LKS dan lembar pekerjaan kelompok. Saat melaksanakan kegiatan kelompok guru menekankan anggota tim haruslah menjadi yang terbaik untuk menolong teman lain yang mengalami kesulitan. Antaranggota tim perlu saling mendukung untuk mengerjakan tugas yang diberikan.

Guru membagikan teks prosedur yang berjudul "Cara Membuat Ayam Goreng Tepung". Di bagian bawah teks berisi soal-soal yang harus didiskusikan semua kelompok. Guru mengarahkan semua siswa membaca teks dengan cara membaca dalam hati selama 10 menit.

Setelah selesai membaca dalam hati, guru mengarahkan masing-masing kelompok mengerjakan tugas 5 butir soal. Kelima soal wajib dikerjakan bersama lewat diskusi dalam kelmpok. Karena itu, agar semua berperan, guru mengarahkan dibuat pembagian tugas dalam kelompok, sehingga semua bertanggung jawab.

\section{3) Melaksanakan Permainan (Games)}

Setelah menyelesaikan tugas kelompok, siswa masuk dalam permainan. Permainan diwakili setiap siswa dari masing-masing kelompok pada meja yang telah disiapkan guru. Di meja tersebut terdapat kartu bernomor yang berhubungan dengan nomor-nomor pertanyaan pada lembar permainan yang harus dikerjakan peserta. Siswa yang lain mengerjakan tugas yang sama dengan utusannya di depan.

Pada tahap ini, siswa tampak tegang ketika guru mengarahkan mereka masuk dalam permainan. Setiap kelompok harus mengutus 1 orang untuk mencambut nomor. Karena itu, siswa dalam kelompok saling tunjuk menjadi utusan di depan.Tetapi, guru memotivasi siswa supaya tidak perlu takut untuk bermain di depan, sehingga semua kelompok dapat mengutus 1 anggota ke depan untuk bermain. Guru telah menyiapkan nomor yang akan dicabut sesuai nomor soal dalam teks. Guru mengarahkan, jika utusan kelompok mencabut nomor undian 1, berarti maka semua anggota kelompok tersebut mengerjakan soal nomor 1 , begitu seterusnya.

Pada tahap game suasana menjadi agak gaduh, karena siswa yang mencabut nomor undian mengangkat nomor tersebut dan memperlihatkan kepada teman-teman dalam kelompoknya. Mereka dengan cepat mengerjakan tugas sesuai nomor undian yang dicabut temannya di depan. Saat mengerjakan, siswa tidak boleh melihat teks bacaan. Siswa begitu serius mengerjakan tugas dalam kelompok, tanpa terkekang langsung merumuskan pendapat untuk diusulkan menjadi jawaban kelompok. Karena terbatasnya waktu yang diberikan guru, semua kelompok dapat merumuskan jawaban sesuai nomor undian yang dicabut.

\section{4) Tournament (Turnamen)}

Kegiatan ini dilakukan setelah permaianan. Turnamen diikuti semua siswa dari semua kelompok. Satu meja ditempati oleh setiap siswa mewakili kelompok yang kemampuan akademiknya setara. Mereka berlomba mengerjakan tugas yang diberikan guru. Tahap ini sekaligus juga pemberian tes individu kepada siswa. Karena itu, sebelum berlomba, guru mengarahkan siswa bekerja secara individu, bukan lagi kelompok. Posisi tempat duduk siswa diacak, siswa yang tadinya sekelompok tidak boleh duduk berdekatan. Guru membagikan soal kepada siswa yang sama dikerjakan secara kelompok. Penilaian akan dilihat dari ketepatan waktu mengerjakan soal dan ketepatan menelaah struktur teks prosedur yang telah dibaca bersama.

Pada tahap tournament ketegangan kembali dialami siswa, karena tugas mereka tidak lagi dikerjakan secara bersama,tetapi sendiri. Karenaa itu, dari hasil pengamatan begitu tampak, siswa berusaha mengerjakan soal-soal yang telah diberikan, bahkan mereka tidak mau lagi diganggu oleh teman-teman yang duduk di samping. Mereka sangat serius dan antusias mengerjakan soal-soal yang diberikan, apalagi guru menjanjikan, siapa yang masuk dalam 5 besar nilai tertinggi akan mendapatkan hadiah. Karena motivasi guru ini, siswa semakin bersemangat mengerjakan soal yang diberikan.

\section{5) Penghargaan terhadap Usaha Kelompok}

Tahap ini merupakan bagian akhir dari pelaksanaan pembelajaran menelaah struktur teks prosedur dengan model TGT atau juga tahap penutup. Sebelum memberikan penghargaan, guru melakukan refleksi dengan siswa. Guru melakukan tanya jawab dengan siswa tentang pembelajaran 
yang baru saja dilaksanakan. Setelah melakukan refleksi, guru memberikan penghargaan terhadap usaha kelompok yang telah mengikuti pelajaran dengan serius. Setiap kelompok yang menunjukkan kerja keras dan memperoleh kriteria nilai yang ditentukan memperoleh hadiah (reward). Penghargaan tertinggi akan diberikan kepada kelompok yang telah memperoleh hasil terbaik. Tetapi berdasarkan pengamatan, semua kelompok telah bekerja dengan serius dan sungguh-sungguh sehingga semua mendapat hadiah dari guru berupa cokelat.Semua anggota mendapat 1 buah. Tampak dengan penghargaan ini semua siswa sangat senang. Mereka meminta kepada guru untuk melakukan pembelajaran TGT lagi.

Berdasarkan hasil pengamatan, cara guru melaksanakan pembelajaran menelaah strktur teks prosedur sudah dilaksanakan dengan baik. Semua fase pembelajaran TGT dan jenis kegiatan yang ada dalam setiap fase dilaksanakan juga dengan baik oleh guru. Sesuai hasil wawancara dengan guru diperoleh informasi bahwa pembelajaran dengan model TGT membuat siswa aktif, antusias, dan senang mengikuti pembelajaran. Data dari guru didukung pula oleh data dari siswa. Saat peneliti menanyakan pendapat siswa tentang penggunaan TGT dalam pembelajaran, siswa yang diwawancarai memberikan informasi bahwa mereka senang dengan pembelajaran menelaah struktur teks prosedur, karena saya baru mengerti tentang teks prosedur. Dan juga penggunaan TGT sangat menarik, karena menantang terlibat dalam permainan dan perlombaan mendalami materi yang dipelajari. Menurut saya hendaknya guru dapat menggunakan lagi model TGT ini untuk materi pembelajaran yang lain karena menarik.

\section{Kemampuan Siswa Kelas VIII SMP Negeri 1 Essang Memahami Struktur Teks Prosedur dengan Model Teams Games Tournament (TGT)}

Dari pembelajaran yang telah dilaksanakan dengan model Teams Games Tournament (TGT) yang diikuti dengan tes diperoleh juga gambaran tentang kemampuan siswa kelas VIII SMP Negeri 1 Essang memahami struktur teks prosedur. Gambaran tentang kemampuan siswa memahami struktur teks prosedur diperoleh berdasarkan hasil tes. Kemampuan siswa memahami struktur teks prosedur tergambar pada tabel berikut ini.

Tabel 1. Kemampuan Siswa Memahami Struktur Teks Prosedur

\begin{tabular}{|c|c|c|c|c|c|c|c|c|}
\hline \multirow{2}{*}{ No. } & \multirow{2}{*}{ Siswa } & \multicolumn{5}{|c|}{ Butir Soal \& Skor } & \multirow{2}{*}{$\begin{array}{c}\text { Jumlah } \\
\text { Skor }\end{array}$} & \multirow{2}{*}{ Nilai } \\
\hline & & 1 & 2 & 3 & 4 & 5 & & \\
\hline 1. & 01 & 4 & 3 & 4 & 3 & 4 & 18 & 90 \\
\hline 2. & 02 & 4 & 2 & 4 & 2 & 4 & 16 & 80 \\
\hline 3. & 03 & 4 & 2 & 4 & 2 & 4 & 16 & 80 \\
\hline 4. & 04 & 4 & 3 & 3 & 3 & 4 & 17 & 85 \\
\hline 5. & 05 & 4 & 3 & 4 & 3 & 4 & 18 & 90 \\
\hline 6. & 06 & 4 & 3 & 4 & 3 & 4 & 18 & 90 \\
\hline 7. & 07 & 4 & 3 & 4 & 3 & 3 & 17 & 85 \\
\hline 8. & 08 & 4 & 3 & 4 & 3 & 4 & 18 & 90 \\
\hline 9. & 09 & 4 & 3 & 4 & 3 & 4 & 18 & 90 \\
\hline 10. & 010 & 4 & 3 & 3 & 4 & 0 & 14 & 70 \\
\hline 11. & 011 & 4 & 3 & 4 & 3 & 4 & 18 & 90 \\
\hline 12. & 012 & 4 & 3 & 4 & 3 & 4 & 18 & 90 \\
\hline 13. & 013 & 4 & 2 & 4 & 2 & 4 & 16 & 80 \\
\hline 14. & 014 & 4 & 3 & 3 & 3 & 4 & 17 & 85 \\
\hline 15. & 015 & 4 & 3 & 4 & 3 & 4 & 18 & 90 \\
\hline 16 & 016 & 4 & 3 & 3 & 3 & 4 & 17 & 85 \\
\hline 17. & 017 & 2 & 3 & 3 & 3 & 4 & 15 & 75 \\
\hline 18. & 018 & 4 & 3 & 3 & 3 & 4 & 17 & 85 \\
\hline 19. & 019 & 4 & 3 & 3 & 3 & 4 & 17 & 85 \\
\hline 20. & 020 & 2 & 2 & 4 & 3 & 4 & 15 & 75 \\
\hline 21. & 021 & 4 & 3 & 3 & 3 & 4 & 17 & 85 \\
\hline & Jumlah & 80 & 59 & 76 & 61 & 78 & 354 & 1.775 \\
\hline
\end{tabular}


Data hasil tes membaca teks prosedur seperti data pada tabel di atas tergambar jelas bahwa kemampuan siswa memahami teks prosedur pada tabel di atas memperlihatkan variasi. Ada siswa yang nilainya sama, tetapi ada juga yang berbeda. Dari data pada tabel 2 di atas menunjukkan bahwa nilai tertinggi yang diperoleh siswa adalah 90, sedangkan nilai terendah adalah 70 .

Berdasarkan pengolahan data, total skor atau nilai keseluruhan siswa pada 5 aspek penilaian tabel 2 adalah 1.775. Untuk memperoleh gambaran mengenai kemampuan siswa memahami struktur teks prosedur, maka total skor atau nilai siswa ini dibagi dengan banyaknya jumlah siswa dengan perhitungan rumus rata-rata sebagai berikut.

$$
\begin{gathered}
x=\frac{x}{N} \\
x=\frac{1.775}{21}=84.52
\end{gathered}
$$

Setelah data diolah dengan rumus hitung rata-rata diperoleh hasil bahwa nilai rata-rata siswa kelas VIII SMP Negeri 1 Essang secara klasikal adalah 84.52. Nilai rata-rata ini melampaui ketuntasan minimal, yang ditetapkan oleh guru mata pelajaran bahasa Indonesia di Kelas VIII SMP Negeri 1 Essang yakni 75.

Pengolahan data dilanjutkan lagi untuk mengetahui kategori kemampuan siswa memahami teks prosedur. Dapat dijelaskan bahwa dari pedoman tersebut menunjukkan nilai rata-rata klasikal yang diperoleh siswa yakni $\mathbf{8 4 , 5 2}$ yakni berada pada rentang 80-89\%. Dengan demikian, secara kualitatif kemampuan siswa kelas VIII SMP Negeri 1 Essang berada pada kualifikasi mampu.

Kemudian, pengolahan data dilanjutkan untuk mengetahui persentase kemampuan nilai siswa sesuai pedoman yang digunakan, seperti pengolahan data berikut.

Tabel 2. Persentase Rentang Perolehan Skor/Nilai Siswa

\begin{tabular}{|c|c|c|c|}
\hline Rentang & Jumlah & Persentase (\%) & Kualifikasi \\
\hline $90 \%-100 \%$ & 8 & $38.10 \%$ & Sangat mampu \\
\hline $80 \%-89 \%$ & 10 & $47.62 \%$ & Mampu \\
\hline $70 \%-79 \%$ & 3 & $14.28 \%$ & Cukup mampu \\
\hline $60 \%-69 \%$ & 0 & $0 \%$ & Kurang mampu \\
\hline $0 \%-59 \%$ & 0 & $0 \%$ & Tidak mampu \\
\hline
\end{tabular}

Sesuai dengan pegolahan data pada tabel 3 menunjukkan sebaran nilai siswa sebagai berikut.

1. Siswa yang memperoleh nilai pada rentang 90\%-100\% dengan kualifikasi sangat mampu 8 orang $(38.10 \%)$.

2. Siswa yang memperoleh nilai pada rentang $80 \%-89 \%$ dengan kualifikasi mampu, 10 orang $(47,62 \%)$.

3. Siswa yang memperoleh nilai pada rentang 70\%-79\% dengan kualifikasi cukup mampu 3 orang $(14,28 \%)$.

4. Siswa yang meperoleh nilai pada rentang 60-69\% dan 0\%-59\% dengan kualifikasi tidak mampu, tidak ada $(0 \%)$.

Berdasarkan pengelompokan sebaran nilai kemampuan siswa memahami teks prosedur diperoleh data bahwa dari 21 siswa yang mengikuti tes, 20 orang $(95.30 \%)$ orang yang memperoleh nilai ketuntasan, karena memperoleh nilai 75 ke atas, sedangkan 1orang siswa $(4.70 \%)$ harus mengikuti remedial, karena belum tuntas, atau belum mencapai nilai 75 sebagai kriteria ketuntasan minimal.

Hasil penelitian ini mengungkapkan juga kemampuan siswa memahami struktur teks prosedur pada setiap butir soal yang dijadikan indikator penilaian. Berdasarkan pengolahan data diperoleh hasil kemampuan siswa memahami struktur teks prosedur sebagai berikut.

Soal nomor 1, rata-rata adalah $\mathbf{8 3 , 6 8}$.

Soal nomor 2, rata-rata adalah $\mathbf{7 0 . 2 3}$

Soal nomor 3, rata-rata adalah $\mathbf{9 0 . 4 7}$

Soal nomor 4 , rata-rata adalah $\mathbf{7 9 . 7 6}$ 


\section{Soal nomor 5, rata-rata adalah $\mathbf{9 2 . 8 5}$}

Dari pengolahan data di atas terungkap bahwa dari 5 butir soal yang dijadikan sebagai indikator penilaian, nilai tertinggi yang diperoleh siswa adalah soal nomor 5, yakni "membuat kesimpulan akhir isi teks" dengan nilai rata-rata 92.85. Nilai terendah yang diperoleh siswa pada soal nomor 2, yakni "merumuskan tujuan akhir isi teks dalam satu pargraf ".

Terciptanya pembelajaran yang efektif, menarik, dan menyenangkan bagi siswa tidak lepas dari keterampilan guru mengelola pembelajaran, dengan memilih model pembelajaran yang tepat, sesuai dengan kompetensi dasar atau materi pembelajaran. Temuan penelitian ini mendukung pendapat ahli bahwa pemilihan model pembelajaran yang sesuai merupakan salah satu kunci keberhasilan pembelajaran. Guru yang baik akan memberikan motivasi dan inspirasi melalui cara mengajar yang menyenangkan (Johnson,2008:4). Temuan ini diperkuat juga oleh hasil penelitian Momongan, K., Paath, R., \& Meruntu, (2015) yang meneliti, Kemampuan Menulis Karangan Deskripsi Melalui Model Pebelajaran Think Pair Share (TPS) yang mengungkaplkan bahwa keberhasilan guru dalam pembelajaran salah satu terletak pada ketepatan memilih model pembelajaran yang sesuai.

Fase-fase pembelajaran TGT yang digunakan dalam pembelajaran memahami struktur teks prosedur dalam penelitian ini, ternyata memberikan rangsangan kepada siswa menjadi aktif dan antusias mengikuti pembelajaran apalagi di dalamnya ada permaianan dan perlombaan untuk menjadi yang terbaik, memotivasi siswa bekerja dengan sungguh mengerjakan tugas yang diberikan guru. Hal ini dipertegas Kurniasari (https;//rizardian.blogspot.com/2012/11/) bahwa terdapat lima komponen utama yang perlu dilaksanakan dalam belajar kooperatif model TGT, yakni (1) presentasi kelas, (2) kegiatan kelompok, (3) permainan (games), (4) turnamen (tournament) dan (5) penghargaan terhadap usaha kelompok, di mana kelima komponen ini menjadi satu kesatuan yang membuat siswa bekerja sama secara aktif, saling berbagi,dan saling bertukar pendapat. Oleh sebab itu, proses pembelajaran menelaah struktur teks prosedur dengan model TGT, yang telah dilaksanakan dalam penelitian memberikan dampak positif terhadap keaktivan siswa mengikuti pembelajaran dan kemampuan memahami struktur teks prosedur. Temuan ini diperkuat hasil wawancara dengan guru dan siswa. Diperoleh informasi bahwa pembelajaran dengan model TGT membuat siswa aktif, antusias, dan senang mengikuti pembelajaran, Guru mengungkapkan TGTmudah dilaksanakan, sehingga memudahkan siswa mengerjakan tugas yang diberikan.Tidak itu saja,dengan belajar bersama secara tim, dalam permaianan (game) maupun turnamen (tournament) membuat siswa sangat menguasai struktur teks prosedur yang dipelajari. Kelebihan TGT menurut guru adalah siswa yang tergolong pinter dapat mengajari siswa yang tergolong kurang. Dalam TGT ini juga semua siswa diperlakukan sama dan adil. Hal ini pun diperkuat oleh siswa yang mengungkapkan penggunaan model TGT membuat mereka tidak bosan mengikuti pembelajaran.

Terlaksananya pembelajaran dengan model TGT memahami struktur teks prosedur memberi efek yang positif terhadap kemampuan siswa memahami struktur teks prosedur. Data hasil tes membaca teks prosedur kemampuan siswa memahami teks prosedur tergolong tinggi. Nilai tertinggi yang diperoleh siswa adalah 90, sedangkan nilai terendah yang diperoleh siswa adalah 70 . Nilai rata-rata klasikal yang diperoleh siswa kelas VIII SMP Negeri 1 Essang adalah 84.52. Nilai rata-rata ini melampaui ketuntasan minimal, yang ditetapkan oleh guru mata pelajaran bahasa Indonesia kelas VIII SMP Negeri 1 Essang yakni 75. Dengan demikian, secara kualitatif kemampuan siswa kelas VIII SMP Negeri 1 Essang memahami struktur teks prosedur berada pada kualifikasi mampu.

Diperoleh juga temuan bahwa kemampuan siswa memahami teks prosedur menunjukkan dari 21 siswa yang mengikuti tes, 20 orang siswa (95.30\%) memperoleh nilai ketuntasan, karena memperoleh nilai 75 ke atas, sedangkan hanya 1 orang siswa $(4.70 \%)$ harus mengikuti remedial, karena belum tuntas atau belum mencapai nilai 75 sebagai kriteria ketuntasan minimal.

\section{SIMPULAN}

1) Proses pembelajaran memahami struktur teks prosedur dengan model TGT terdiri atas lima komponen atau fase utama, yakni (1) presentasi kelas, (2) kegiatan kelompok, (3) permainan 
(games), (4) turnamen (tournament) dan (5) penghargaan terhadap usaha kelompok. Klima fase ini menjadi satu kesatuan yang membuat siswa bekerja sama secara aktif, saling berbagi, dan saling bertukar pendapat. Proses pembelajaran menelaah struktur teks prosedur dengan model TGT, berlangung denganmenarik dan tidak membosankan. Dengan belajar bersama secara tim, dalam permaianan (game) maupun turnamen (tournament) membuat siswa menguasai struktur teks prosedur yang dipelajari.

2) Terlaksananya pembelajaran dengan model TGT dengan baik memberi efek yang positif terhadap kemampuan siswa memahami struktur teks prosedur. Nilai rata-rata klasikal yang diperoleh siswa kelas VIII SMP Negeri 1 Essang adalah 84.52 dengan kualifikasi mampu dan melampaui ketuntasan minimal, yang ditetapkan oleh guru mata pelajaran bahasa Indonesia, yakni 75. Diperoleh juga temuan bahwa dari 21 siswa yang mengikuti tes, 20 orang siswa (95.30\%) memperoleh nilai ketuntasan, karena memperoleh nilai 75 ke atas, sedangkan hanya 1 orang siswa $(4.70 \%)$ harus mengikuti remedial, karena belum tuntas atau belum mencapai nilai 75 sebagai kriteria ketuntasan minimal. 


\section{DAFTAR PUSTAKA}

Burns, 1996. Teaching Reading in Today's Elementary Schools. Boston. Hougthon Mifflin Company.

Depdikbud. 2013. Kurikulum 2013. Jakarta: Puskur. Kurniasari (https;//rizardian.blogspot.com/2012/11/).

Johnson, L.A.2008. Pengajaran yang Kreatif, Menarik. (Terjemahan Dani Dharyani). Jakarta: PT Indeks.

Mahsun, M.S. 2014. Teks dalam Pembelajaran Bahasa Indonesia Kurikulum 2013. PT Raja Grafindo: Persada

Momongan, K., Paath, R., \& Meruntu, O. 2015. Kemampuan Menulis Karangan Deskripsi Melalui Model Pebelajaran Think Pair Share (TPS) Siswa Kelas Xc SMA Kristen 1 Tomohon. Jurnal Fakultas Bahasa dan Seni - Kompetensi, Vo 3, No. 2 (2015): BahasaIndonesia. http://id.portalgaruda.org/?refl=author\&mod=profile\&id=476808.

Mundung, S., Pelelalu, \& Meruntu. 2014. Penerapan Model Kooperatif Concept Sentences dalam Pembelajaran Menulis Narasi Siswa Kelas VII SMP Negeri 3 Ranoyapo. . Jurnal Fakultas Bahasa dan Seni - Kompetensi, Vo 3, No. 2 (2015): BahasaIndonesia. http://scholar.google.co.id/citations?user/?Ffl=AAAAA\&hl=id.

Syafi'ie. 1993. Pengajaran Keterampilan Membaca. Malang : Universitas Negeri Malang.

Wiratin. 2004. Peningkatan Kemampuan Membaca Pemahaman dengan Strategi Bertanya Siswa Kelas II SMP 9 Banjarbaru. Malang: UM. 